\title{
Effects of Zinc Oxide Nanoparticles in HUVEC: Cyto- and Genotoxicity and Functional Impairment After Long-Term and Repetitive Exposure in vitro
}

This article was published in the following Dove Press journal: International Journal of Nanomedicine

\author{
Nikolaus Poier ${ }^{1,2}$ \\ Johannes Hochstöger ${ }^{1,2}$ \\ Stephan Hackenberg ${ }^{3}$ \\ Agmal Scherzad ${ }^{3}$ \\ Maximilian Bregenzer ${ }^{3}$ \\ Dominik Schopper ${ }^{1,2}$ \\ Norbert Kleinsasser ${ }^{1,3}$ \\ 'Department of Otorhinolaryngology, \\ Head and Neck Surgery, Kepler \\ University Hospital, Linz 402I, Austria; \\ ${ }^{2}$ Medical Faculty, Johannes Kepler \\ University Linz, Linz 4040, Austria; \\ ${ }^{3}$ Department of Otorhinolaryngology, \\ Plastic, Aesthetic and Reconstructive \\ Head and Neck Surgery, University of \\ Wuerzburg, Würzburg 97080 , Germany
}

Correspondence: Nikolaus Poier

Krankenhausstraße 9, Linz 402I, Austria

$\mathrm{Tel}+436502409889$

Email nikolaus.poier@kepleruniklinikum.at
Purpose: The present study focuses on threshold levels for cytotoxicity after long-term and repetitive exposure for HUVEC as a model for the specific microvascular endothelial system. Furthermore, possible genotoxic effects and functional impairment caused by ZnO NPs in HUVEC are elucidated.

Methods: Thresholds for cytotoxic effects are determined by the 3-(4,5-dimethylthiazol-2yl)-2,5-diphenyltetrazolium bromide (MTT) and Annexin V assay. To demonstrate DNA damage, single-cell microgel electrophoresis (comet) assay is performed after exposure to sub-cytotoxic concentrations of ZnO NPs. The proliferation assay, dot blot assay and capillary tube formation assay are also carried out to analyze functional impairment.

Results: NPs showed to be spherical in shape with an average size of 45-55 $\mathrm{nm}$. Long-term exposure as well as repetitive exposure with $\mathrm{ZnO} N$ Ps exceeding $25 \mu \mathrm{g} / \mathrm{mL}$ lead to decreased viability in HUVEC. In addition, DNA damage was indicated by the comet assay after longterm and repetitive exposure. Twenty-four hours after long-term exposure, the proliferation assay does not show any difference between negative control and exposed cells. Forty-eight hours after exposure, HUVEC show an inverse concentration-related ability to proliferate. The dot blot assay provides evidence that ZnO NPs lead to a decreased release of VEGF, while capillary tube formation assay shows restriction in the ability of HUVEC to build tubes and meshes as a first step in angiogenesis.

Conclusion: Sub-cytotoxic concentrations of ZnO NPs lead to DNA damage and functional impairment in HUVEC. Based on these data, ZnO NPs may affect neo-angiogenesis. Further investigation based on tissue cultures is required to elucidate the impact of $\mathrm{ZnO}$ NPs on human cell systems.

Keywords: zinc oxide, nanoparticles, cytotoxicity, genotoxicity, toxicity

\section{Introduction}

Over the last decades, nanotechnology has become increasingly important in industry, biomedicine, and research. ${ }^{1}$ In industrialized countries, a wide range of nanoparticles (NPs) based on various chemical structures and particle sizes are used. ${ }^{2}$ The European Union recommends defining nanomaterials as particles of one or more external dimensions in the size range from $1 \mathrm{~nm}$ to $100 \mathrm{~nm}^{3}$

In manufacturing processes, inhalation is the most relevant exposure route for NPs. ${ }^{1}$ For the individual, the main exposure route is dermal application. Cosmetics like sunscreens, for example, benefit from the use of minor-sized particles instead of bulky substances to improve lubricity and UV-protection. ${ }^{1} \mathrm{ZnO}$ NPs are the most commonly used NPs in these two sectors. ${ }^{4}$ 
An important question that still serves as the basis for contradictory discussion in the literature today is whether $\mathrm{ZnO}$ NPs are able to pass through human skin and induce systemic damage after dermal application. While there is evidence that $\mathrm{ZnO}$ NPs cannot penetrate the intact dermis, ${ }^{5-7}$ there are other studies that show that ZnO NPs can harm skin keratinocytes, ${ }^{8}$ and $\mathrm{Zn}$ can be detected in blood and urine after dermal application on healthy skin. ${ }^{9}$ Particularly in the case of topical application of $\mathrm{ZnO} \mathrm{NP}$-containing sunscreens on predamaged skin, eg, scratched, sunburned or toxically predamaged skin, potential accumulative systemic effects should be considered..$^{10}$ Moreover, additional adverse effects via phototoxicity may also be of importance. ${ }^{1}$

It has been shown that ZnO NPs can cause damage by passing through the air-blood barrier after inhalation. ${ }^{11,12}$ Hence, they can easily penetrate into the bloodstream ${ }^{13}$ and cause adverse systemic effects. Sun et al demonstrated a time-, dose- and concentration-dependent cytotoxicity, increased permeability and inflammatory response of human cardiac microvascular endothelial cells treated with ZnO NPs. ${ }^{14}$ These findings were confirmed in HUVEC by Paszek et al, who observed substantial structural deterioration and functional impairment already at subtoxic doses. ${ }^{15}$ Suzuki et al showed that ZnO NPs can accelerate atherosclerosis of HUVEC by increased macrophage adhesion and cholesterol uptake, ${ }^{16}$ which was also shown by Yan et al in human coronary endothelial cells. ${ }^{17}$ Other studies detected increased expression of pro-inflammatory surface proteins in various endothelial cell systems. ${ }^{18-20}$

Different mechanisms seem to contribute to the toxic effects of metal NPs. ${ }^{21}$ Direct ROS generation is well known to unfold cyto- and genotoxic impact. ${ }^{22,23}$ Others like mitochondrial malfunction, metal ion release and calcium homeostasis are discussed to contribute to the genotoxic effects of $\mathrm{ZnO} \mathrm{NPs}$, too. ${ }^{24-26}$

Despite increasing research interest, there is still a lack of data concerning the biological effects of $\mathrm{ZnO}$ NPs on the specific microvascular endothelial system. Functional and cytotoxic effects of ZnO NPs in various endothelial, as well as other cell systems, have been shown, ${ }^{27}$ whereas data regarding genotoxicity are generally rare and partly contradictory. ${ }^{1,28-30}$

Many studies provide evidence that nanomaterials harm cells in different ways. ${ }^{24,25,31,32}$ At the same time, they are promising for a large number of medical applications, eg, drug delivery, antibacterial coating, medical imaging and cancer therapy. ${ }^{33-36}$ Therefore, they are discussed as a double-edged sword. ${ }^{37}$
To the best of our knowledge, only very little data are available concerning the cytotoxicity of $\mathrm{ZnO}$ NPs in HUVEC, and essentially no data concerning genotoxicity. Therefore, the aim of the present study is to further investigate possible cytotoxic and genotoxic effects, as well as functional impairment induced by $\mathrm{ZnO}$ NPs in HUVEC as a primary cell model for the specific microvascular endothelial system.

\section{Materials and Methods Chemicals and Their Characterization}

Preparation and processing were done according to published protocols. $^{30,38} \mathrm{ZnO} \mathrm{NPs} \mathrm{(ZnO,} \mathrm{99.9 \%} \mathrm{purity,} \mathrm{average} \mathrm{particle}$ size: $20 \mathrm{~nm}$ ) were obtained from MK Impex Corp (Product number: MKN-ZnO-020, Lot number: VA0809; Mississauga, Ontario, Canada). NPs were characterized using a Zeiss transmission electron microscope EM 900 (Carl Zeiss AG, Oberkochen, Germany). Furthermore, dynamic light scattering and the assessment of the surface zeta potential of the dispersion were performed with a ZetaSizer 3000 HSA (Malvern Instruments Ltd., Malvern, Worcestershire, United Kingdom) at an NP-concentration of $50 \mu \mathrm{g} / \mathrm{mL}$ diluted in cell culture medium ( $\mathrm{pH}$ 7.4) at room temperature in three repetitions. Stock suspension for the cell exposure was prepared as follows: $10 \mathrm{mg}$ NPs were suspended in $870 \mu \mathrm{L}$ of sterilized distilled water. After sonication (Bandelin, Sonopuls HD 60, Berlin, Germany) for $120 \mathrm{~s}$ at a continuous energy level of $4.3 \times 10^{5} \mathrm{~kJ} / \mathrm{m}^{3}$ to obtain NP dispersion, ${ }^{39} 30 \mu \mathrm{L}$ of $15 \mathrm{mg} / \mathrm{mL}$ bovine serum albumin (BSA; Carl Roth GmbH+Co.KG, Karlsruhe, Germany) was added to stabilize the dispersion. Then, $100 \mu \mathrm{L}$ of $10 \mathrm{x}$ concentrated sterile phosphate-buffered saline (PBS) was added to achieve a physiological salt concentration with $\mathrm{pH}$ 7.4 in the ZnO NP stock suspension. To establish the working concentrations for cell treatment the stock suspension was diluted with Endothelial cell growth medium with supplements (ECGM; Provitro GmbH, Berlin, Germany) and 1\% penicillin/streptomycin. To analyze the threshold of cytotoxicity concentrations between 1 and $50 \mu \mathrm{g} / \mathrm{mL}$ were produced. For sub-toxic testing of functional impairment and genotoxicity, concentrations of $1,5,10$ and $15 \mu \mathrm{g} / \mathrm{mL}$ were used.

\section{HUVEC Culture}

HUVEC (pooled donors, PromoCell GmbH, Heidelberg, Germany) were isolated according to procedures described in a previous study by our group. ${ }^{40}$ Two cell lines were used in passages 3 to 9 . Cells were cultured in endothelial 
cell growth medium with supplements (ECGM; Provitro $\mathrm{GmbH}$, Berlin, Germany) and 1\% penicillin/streptomycin.

\section{Cytotoxicity: Viability Evaluation}

To investigate long-term exposure cells were seeded in 96well round-bottom plates at a density of $10^{4}$ cells per well and incubated at $37^{\circ} \mathrm{C}$ and $5 \% \mathrm{CO}_{2}$. After $24 \mathrm{hrs}$ of incubation, cells were treated with $20,25,30,35,40,45$ and $50 \mu \mathrm{g} / \mathrm{mL} \mathrm{ZnO} \mathrm{NPs} \mathrm{for} \mathrm{another} 24 \mathrm{hrs}$ at $37^{\circ} \mathrm{C}$ and $5 \%$ $\mathrm{CO}_{2} .1 \mathrm{mM}$ Tert-butyl hydroperoxide (t-BHP; SigmaAldrich, St. Louis, MO, USA) served as a positive control, and ECGM without $\mathrm{ZnO}$ NPs as a negative control. After long-term exposure, the 3-(4,5-dimethylthiazol-2-yl)-2,5diphenyl tetrazolium bromide (MTT; Sigma-Aldrich, St. Louis, MO, USA) colorimetric staining assay was used to assess cell viability. ${ }^{41}$ After $3.5 \mathrm{hrs}$ of inoculation at $37^{\circ} \mathrm{C}$ with $5 \% \mathrm{CO}_{2}$, the MTT solution was replaced by isopropanol. After $20 \mathrm{~min}$ at room temperature (RT), the color conversion of the blue formazan dye was measured by a microplate absorbance reader (BioTek Instruments, Inc., Winooski, VT, USA) at a wavelength of $570 \mathrm{~nm}$.

To perform repetitive exposure HUVEC were seeded in 24-well round-bottom plates at a density of $5 \times 10^{4}$ cells per well three times for each concentration. After $24 \mathrm{hrs}$ of incubation, they were exposed to 10,20 and $50 \mu \mathrm{g} / \mathrm{mL}$ $\mathrm{ZnO} \mathrm{NP}$ suspension, and $10 \mathrm{mM}$ t-BHP for $1 \mathrm{hr}$, respectively, followed by a washing step with PBS. After initial exposure, the first MTT assay was performed for each concentration (control, 10, 20, $50 \mu \mathrm{g} / \mathrm{mL}, \mathrm{t}-\mathrm{BHP}$ ). The remaining wells were incubated with ECGM without $\mathrm{ZnO}$ NPs for $1 \mathrm{hr}$ followed by another hour of $\mathrm{ZnO} \mathrm{NP}$ exposure. This procedure was repeated twice. Following the third exposure, a further MTT assay was performed and the remaining cells were incubated in fresh ECGM for a 24-hr regeneration period, after which a final MTT assay was competed (Figure 1).

\section{Cytotoxicity: Apoptosis Evaluation}

For the evaluation of apoptosis, HUVEC were seeded in 12-well round-bottom plates at a density of $10^{5}$ cells per well. After $24 \mathrm{hrs}$ of incubation at $37^{\circ} \mathrm{C}$ and $5 \% \mathrm{CO}_{2}$, cells were exposed to $20,25,30,35,40,45,50 \mu \mathrm{g} / \mathrm{mL} \mathrm{ZnO}-\mathrm{NP}$ suspension. Again, $1 \mathrm{mM}$ t-BHP served as a positive control and ECGM as a negative control. The Annexin V apoptosis assay was performed after $24 \mathrm{hrs}$ long-term exposure. Cells in suspension and adherent cells were harvested, followed by centrifugation at $1500 \mathrm{rpm}$ for 5 min and resuspension in binding buffer $(100 \mu \mathrm{L} ; 10 \mathrm{x}$ Annexin V Binding Buffer, BD Biosciences, San Jose, CA, USA). This cell suspension was then transferred to a $5 \mathrm{~mL}$ culture tube. Propidium iodide (5 $\mu \mathrm{L}$; Propidium Iodide Staining Solution, BD Biosciences, San Jose, CA, USA) and Annexin V (5 $\mu \mathrm{L}$; APC Annexin V, BD Biosciences, San Jose, CA, USA) were added to each tube. After 15 min of incubation at RT in the dark, the cells were resuspended with $400 \mu \mathrm{L}$ binding buffer. A BD

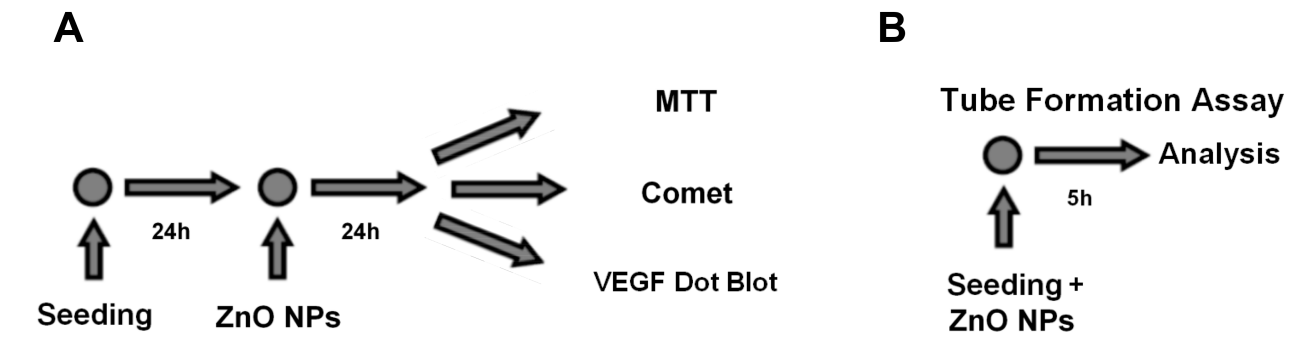

B

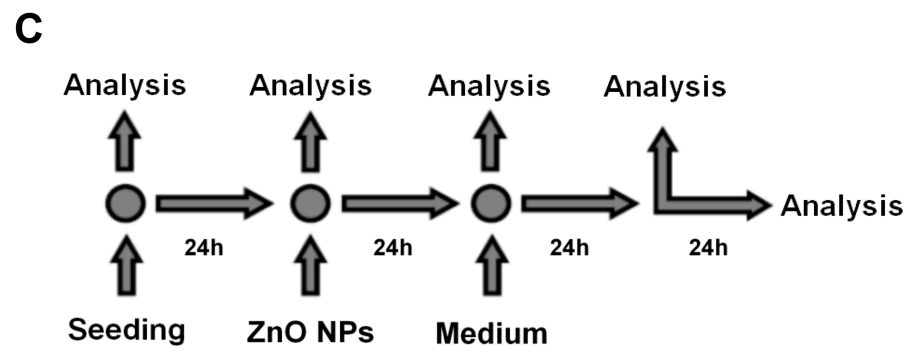

Figure I Experimental design of long-term exposure to ZnO NPs. Twenty-four hours after seeding, HUVEC were exposed to ZnO NPs for further 24 hrs. Then, MTT assay, comet assay and VEGF dot blot were performed (A). For the tube formation assay, HUVEC were seeded on Matrigel together with ZnO NPs and analyzed after 5 hrs (B). Analysis for the proliferation assay was performed at seeding, before treatment, after long-term treatment, 24 hrs after treatment and 48 hrs after treatment (C). 
FACS Canto flow cytometer (BD Biosciences, San Jose, CA, USA) was used to analyze the samples with BD FACSDiva software (version 5.0.3; BD Biosciences, Oxford, United Kingdom).

\section{Genotoxicity: Comet Assay}

The alkaline version of the single-cell microgel electrophoresis (comet) assay was used to show DNA strand breaks and alkali labile as well as incomplete excision repair sites in single cells. ${ }^{42}$

Based on the previously performed cytotoxicological analysis by the MTT assay and Annexin V assay, ZnO NPs were tested in HUVEC at sub-cytotoxic doses of 1,5 and $10 \mu \mathrm{g} / \mathrm{mL}$. Additionally, a negative control was done with pure culture medium, whereas the $200 \mu \mathrm{M}$ directly alkylating methyl methanesulfonate (MMS, Sigma-Aldrich) served as a positive control. Test concentrations were applied for $24 \mathrm{hrs}$. Three subsequent treatment times for $1 \mathrm{hr}$ with intermittent washing steps and regeneration periods of another hour were done in the repetitive exposure setting (Figure 2).

The comet assay was performed and analyzed as previously described. $^{43,44}$ For every test concentration, 50 randomly chosen single cells on each of 2 slides (resulting in a total of 100 cells per test concentration) were semiautomatically analyzed with a fluorescence microscope (Leica Microsystems, Wetzlar, Germany) using a green excitation filter, a dichromatic beam splitter $(580 \mathrm{~nm}$ long pass) and an emission filter (590 nm long pass) at a magnification of 400x. The software COMET 5.5 image system (Kinetic Imaging, Liverpool, UK) was used. Percent of DNA in tail (TD), tail length (TL) and Olive tail moment (OTM) as a multiplication product of the median migration distance and the percentage of DNA in the tail served as outcome parameters. ${ }^{45}$ In our study, the OTM was used for statistical analysis.

\section{Functional Impairment: Proliferation}

\section{Assay}

In order to determine the impact of ZnO NPs on HUVEC's ability to proliferate, cell number and viability were measured before cultivation, after 1 day of cultivation, hence before treatment with $\mathrm{ZnO}$ NPs, after $24 \mathrm{hrs}$ of treatment with various test concentrations of $\mathrm{ZnO}$ NPs, and $24 \mathrm{hrs}$ as well as $48 \mathrm{hrs}$ after treatment. All measurements were done as follows: $3 \times 10^{4}$ HUVEC per well were seeded and cultivated in a 12 -well plate at $37^{\circ} \mathrm{C}$ and $5 \% \mathrm{CO}_{2}$ with ECGM including supplements and $1 \%$ penicillin/streptomycin. After trypsinization and stopping the enzyme reaction as described above, cell number was measured by a Casy Modell TT cell counter (Innovatis AG, Reutlingen, Germany). Every test was performed three times and arithmetic means were calculated in order to achieve higher statistical validity.

\section{Functional Impairment: VEGF Dot Blot}

To examine the impact of $\mathrm{ZnO}$ NPs on the capability of HUVEC to produce and secrete cytokines such as Vascular Endothelial Growth Factor (VEGF) in the paracrine way, a dot blot assay (Raybiotec Inc., Norcross, GA, USA) was performed. The examination of this semiquantitative analysis was performed according to the manufacturer's protocol. Therefore, $5 \times 10^{4}$ HUVEC per well were cultivated 24 hrs in a 12-well plate. To avoid test falsification, since fetal calf serum usually contains VEGF, ECGM without supplements (ie without FCS) was used. In addition, a washing step with PBS was done prior to incubation with treatment solutions for another $24 \mathrm{hrs}$. Next, the supernatant was collected and centrifuged at $1500 \mathrm{rpm}$ at RT for $15 \mathrm{~min}$. This centrifugation step was done twice. Afterwards, the supernatant was frozen and analyzed later. The presence of labelled cytokines was displayed via chemiluminescence using detection buffer and exposure to an X-ray film. Dot

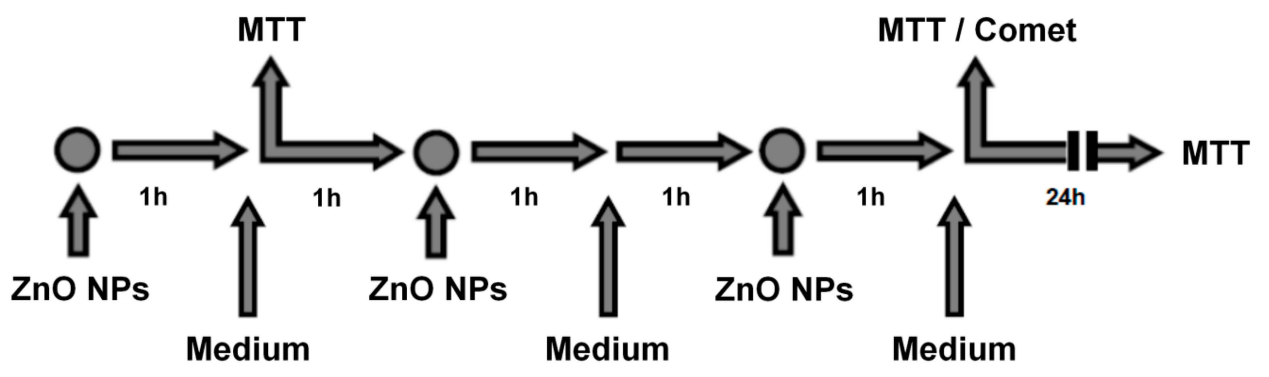

Figure 2 Experimental design of repetitive cell exposure to ZnO NPs. HUVEC were exposed for I hr three subsequent times with washing steps and regeneration periods of I hr in between, followed by a 24-hr regeneration period. MTT assay was performed after I hr of treatment, after $3 \mathrm{hrs}$ of treatment and after the 24-hr regeneration period. Comet assay was performed after $3 \mathrm{hrs}$ of treatment. 
size and intensity represent concentration levels. Integrated density of the dots was automatically analyzed with NIH ImageJ (https://imagej.nih.gov/ij/).

\section{Functional Impairment: Capillary Tube Formation Assay}

The capillary tube formation assay was done to show the possible effects of $\mathrm{ZnO}$ NPs on the ability of vascular endothelial cells to proliferate and form microtubuli as a model of neoangiogenesis and tissue repair. ${ }^{46}$ Therefore, 10 $\mu \mathrm{L}$ of Matrigel (Sigma-Aldrich, St. Louis, MO, USA) was transferred into a special plate ( $\mu$-Slide Angiogenesis plate, ibidi $\mathrm{GmbH}$, Martinsried, Germany) and stored in the incubator under standard conditions. Thereafter, $50 \mu \mathrm{L}$ of the test cell suspension - containing $10^{4}$ cells - was transferred into each well. The plate was incubated as mentioned above and analyzed after 5 and $24 \mathrm{hrs}$. To capture the entire well, four pictures per well were acquired by phase-contrast inverted microscopy (Leica Microsystems, Wetzlar, Germany). In order to achieve the highest possible statistical validity and objectivity, all test concentrations were done as triplicate resulting in 12 pictures per test concentration. The one picture out of four with the best capillary tube formation was selected carefully and used for automatic image analysis, ultimately resulting in three analyzed pictures per test concentration. Tube formation was analyzed automatically by $\mathrm{NIH}$ ImageJ with the Angiogenesis Analyzer plugin ${ }^{47}$ as suggested by DeCicco-Skinner et al. ${ }^{46}$

\section{Statistical Analysis}

Mean values were used for the analysis of dose-dependent effects within treatment groups by the Friedman test. Friedman test is the best available method to detect differences in three or more related samples ${ }^{48}$ and, consequently, it is the method of choice to elucidate dose dependency. For the evaluation of viability, negative controls were defined as $100 \%$. Statistical analysis was performed with SPSS Statistics 25.0 for windows (IBM Corp., Armonk, NY, USA). P-values $<0.05$ were considered as statistically significant.

\section{Results}

\section{Characterization of Nanoparticles}

To characterize the NPs, transmission electron microscopy (TEM) and dynamic light scattering were performed. The mean diameter of the NPs was 45-55 nm and they were spherical in shape. The average diameter of aggregates was $121 \mathrm{~nm}$ with a zeta potential of $-11 \mathrm{mV}$ and a polydispersity index of 0.14 . These findings do not match the specifications provided by the commercial supplier.

\section{Cytotoxicity}

To determine the threshold of cytotoxicity of $\mathrm{ZnO}$ NPs on HUVEC the MTT and Annexin V assays were used. Viability was expressed in percent compared to the untreated control in the MTT assay (Figure 3). Neither assay showed any effect on the viability at concentrations between 5 and $20 \mu \mathrm{g} / \mathrm{mL}$. Concentrations between 35 and $50 \mu \mathrm{g} / \mathrm{mL}$ led to a reduction in viable cells in the MTT assay. Differences showed to be significant in the Friedman test $(\mathrm{p}<0.01)$. In the Annexin V assay, an increase in apoptotic and necrotic cells could also be observed at concentrations above $30 \mu \mathrm{g} / \mathrm{mL}$. Cells treated with $25 \mu \mathrm{g} / \mathrm{mL}$ showed a decreased trend in viability with MTT, as similarly found for the Annexin V assay: 2.0\% apoptotic cells after exposure with $20 \mu \mathrm{g} / \mathrm{mL}, 5.7 \%$ after exposure with 25 $\mu \mathrm{g} / \mathrm{mL}$ and $27.6 \%$ with $30 \mu \mathrm{g} / \mathrm{mL}$ (Figure 4).

Furthermore, we investigated the effects of repetitive exposure to ZnO NPs with the MTT assay. Friedman test indicated significant dose-dependent differences after 1 $(\mathrm{p}=0.032)$ and $3(\mathrm{p}=0.029)$ consecutive $1 \mathrm{hr}$ treatment periods as well as after $24 \mathrm{hrs}$ regeneration period $(\mathrm{p}=0.042$; Figure 5).

\section{Genotoxicity}

There was a significant enhancement of DNA damage as determined by the comet assay in HUVEC exposed to subcytotoxic concentrations of $\mathrm{ZnO}$ NPs as compared to the controls. The long-term exposure $(\mathrm{p}<0.001)$ as well as

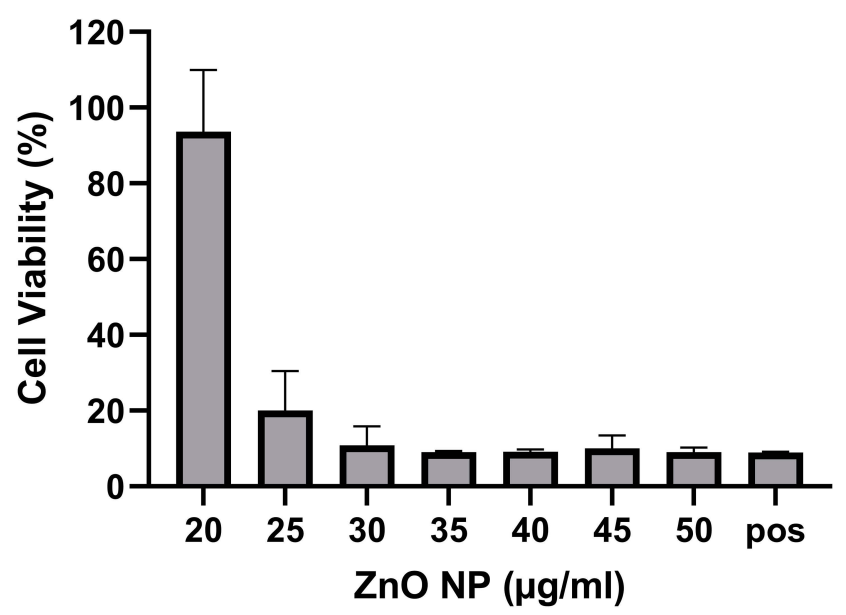

Figure 3 Viability of HUVEC after $24 \mathrm{hr}$ exposure to ZnO NP. The untreated control was defined as $100 \%$. Ten $\mathrm{mM}$ tBHP served as positive control (pos). A significant decrease in HUVEC viability was observed in Friedman test. 

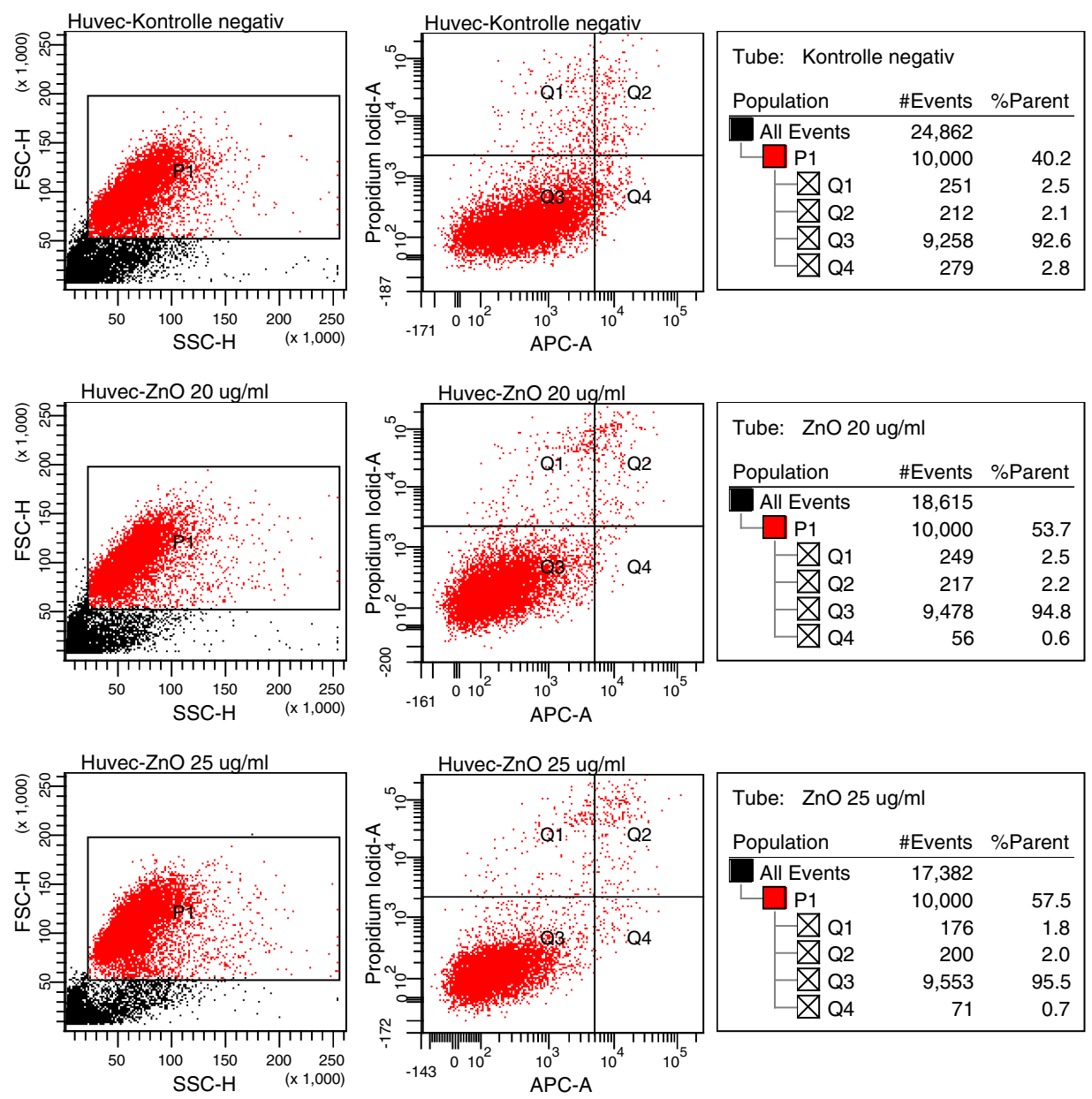

\begin{tabular}{|c|c|c|}
\hline \multicolumn{3}{|c|}{ Tube: $\mathrm{ZnO} 25 \mathrm{ug} / \mathrm{ml}$} \\
\hline Population & \#Events & \%Parent \\
\hline All Events & 17,382 & \\
\hline P1 & 10,000 & 57.5 \\
\hline$\triangle Q 1$ & 176 & 1.8 \\
\hline$\triangle Q 2$ & 200 & 2.0 \\
\hline$\triangle Q 3$ & 9,553 & 95.5 \\
\hline$\vec{\nabla} \mathrm{Q4}$ & 71 & 0.7 \\
\hline
\end{tabular}
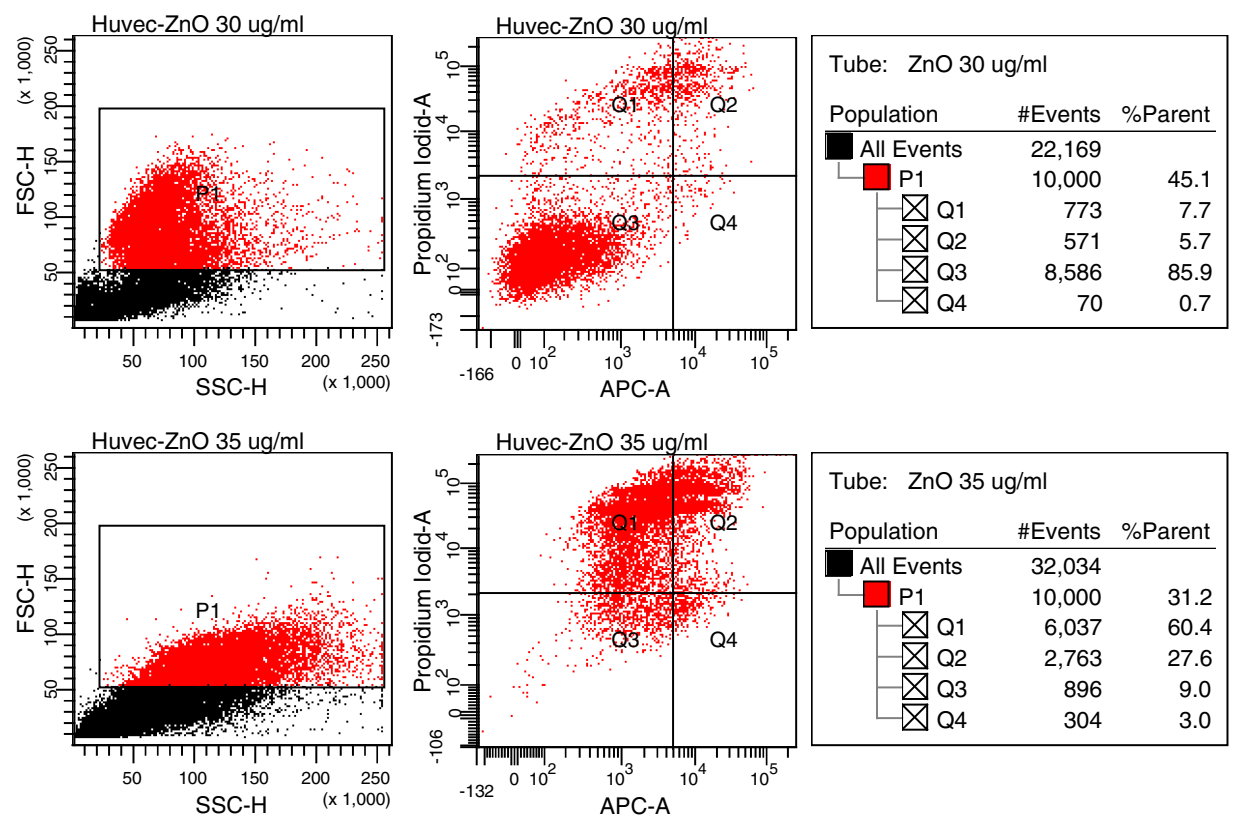

Figure 4 Continued. 

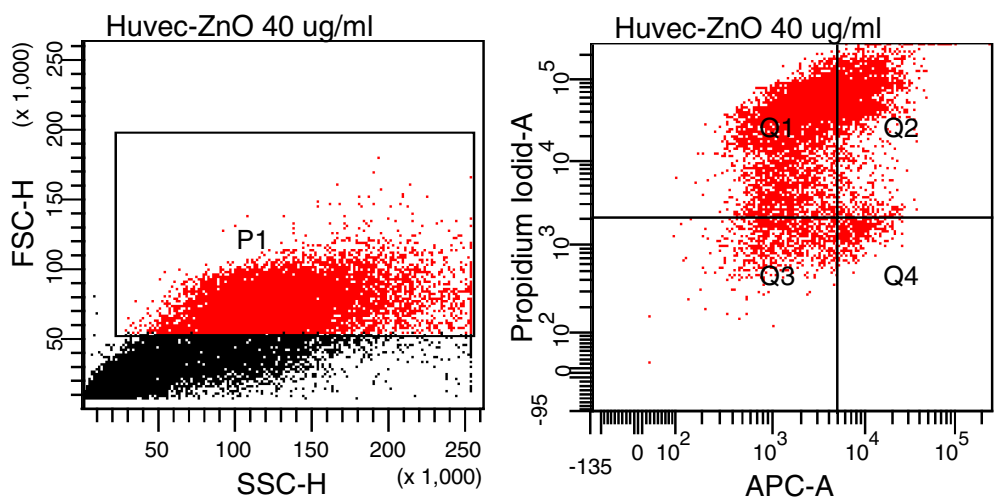

Tube: ZnO $40 \mathrm{ug} / \mathrm{ml}$
\begin{tabular}{lrr} 
Population & \#Events & $\%$ Parent \\
\hline All Events & 23,077 & \\
\hline P1 & 10,000 & 43.3 \\
Q1 & 5,933 & 59.3 \\
Q2 & 2,844 & 28.4 \\
Q3 & 853 & 8.5 \\
Q4 & 370 & 3.7 \\
\hline
\end{tabular}
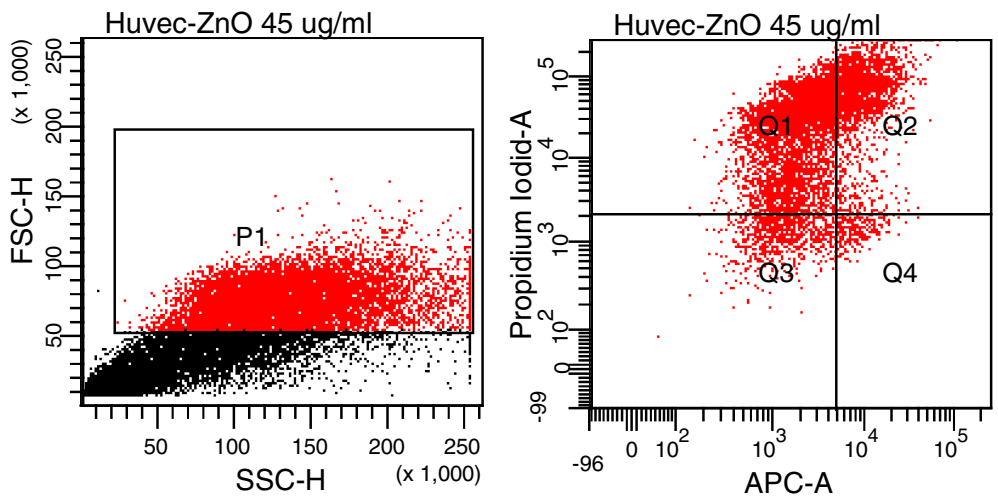

Tube: ZnO $45 \mathrm{ug} / \mathrm{ml}$
\begin{tabular}{lrr} 
Population & \#Events & $\%$ Parent \\
\hline All Events & 20,349 & \\
\hline P1 & 10,000 & 49.1 \\
\hline Q1 & 5,837 & 58.4 \\
Q2 & 3,093 & 30.9 \\
Q3 & 840 & 8.4 \\
Q4 & 230 & 2.3
\end{tabular}
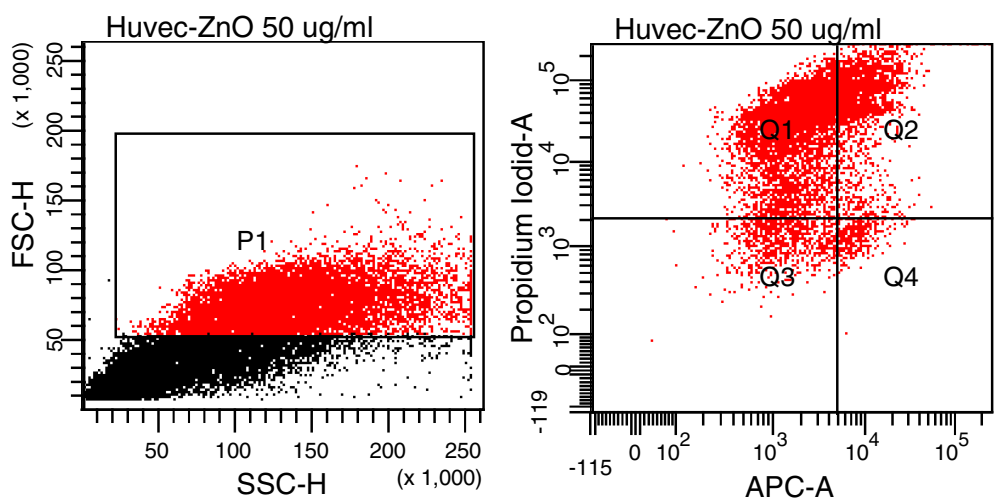

Tube: ZnO $50 \mathrm{ug} / \mathrm{ml}$
\begin{tabular}{lrr} 
Population & \#Events & $\%$ Parent \\
\hline All Events & 25,457 & \\
\hline P1 & 10,000 & 39.3 \\
Q1 & 6,135 & 61.4 \\
Q2 & 2,702 & 27.0 \\
Q3 & 831 & 8.3 \\
Q4 & 332 & 3.3
\end{tabular}
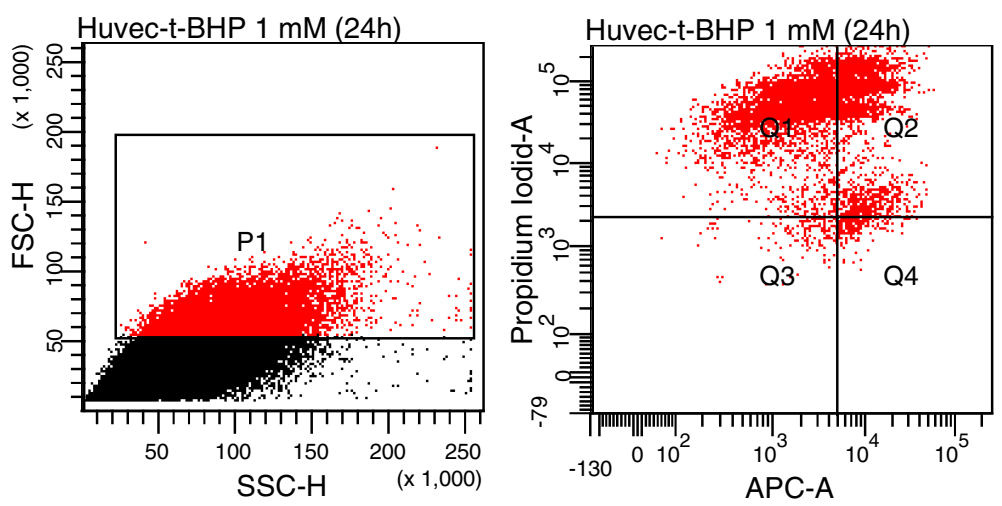

\begin{tabular}{|c|c|c|}
\hline \multicolumn{3}{|c|}{ Tube: t-BHP 1 mM (24h) } \\
\hline Population & \#Events & \%Parent \\
\hline All Events & 49,954 & \\
\hline P1 & 10,000 & 20.0 \\
\hline$\bigotimes$ Q1 & 6,321 & 63.2 \\
\hline$\bigotimes \mathrm{Q} 2$ & 3,316 & 33.2 \\
\hline$\triangle Q$ Q3 & 160 & 1.6 \\
\hline $\bar{\triangle}$ Q4 & 203 & 2.0 \\
\hline
\end{tabular}

Figure 4 Annexin $\mathrm{V}$ assay. Results from HUVEC treated with ZnO NP concentrations of 20, 25, 30, 35, 40, 45 and $50 \mu \mathrm{g} / \mathrm{mL}$, negative and positive control are shown. QI, \% of damaged cells; Q2, \% of necrotic cells; Q3, \% of viable cells; Q4, \% of apoptotic cells. 


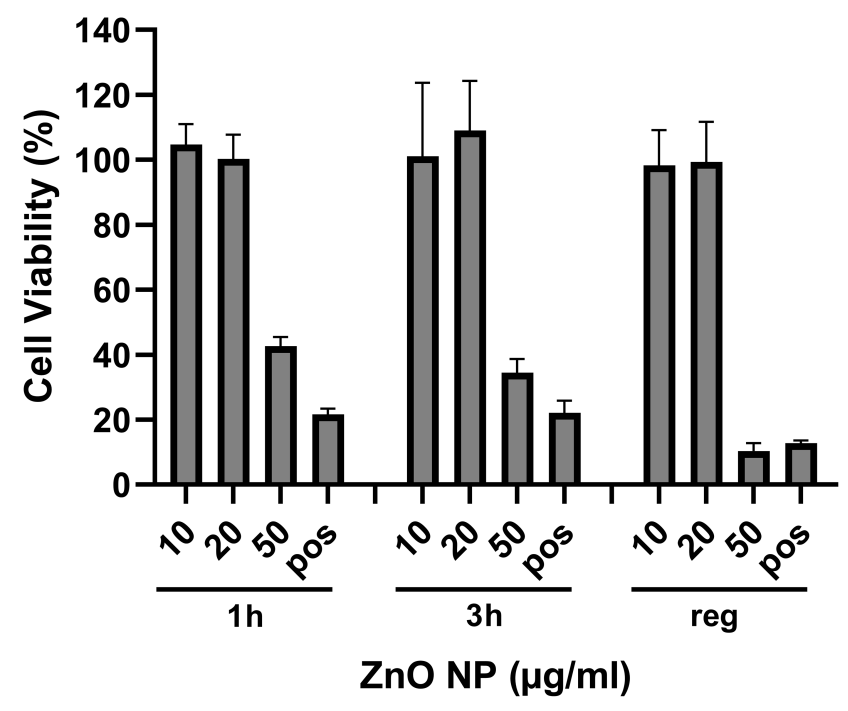

Figure 5 Viability of HUVEC after exposure to ZnO NPs $(\mu \mathrm{g} / \mathrm{mL})$. The untreated control was defined as $100 \%, \mathrm{tBHP} 10 \mathrm{mM}$ served as positive control (pos). The graph shows results after I and 3 consecutive I-hr treatment periods and after a 24-hr regeneration period (reg).

repetitive exposure $(\mathrm{p}<0.001)$ with $\mathrm{ZnO}$ NPs led to an increase in the OTM compared to non-treated cells. In both test-settings, cells treated with MMS, which served as a positive control, also showed enhanced DNA migration (Figure 6).

\section{Functional Impairment}

The proliferation assay showed no significant difference between cells treated with sub-cytotoxic $\mathrm{ZnO}$ NPs

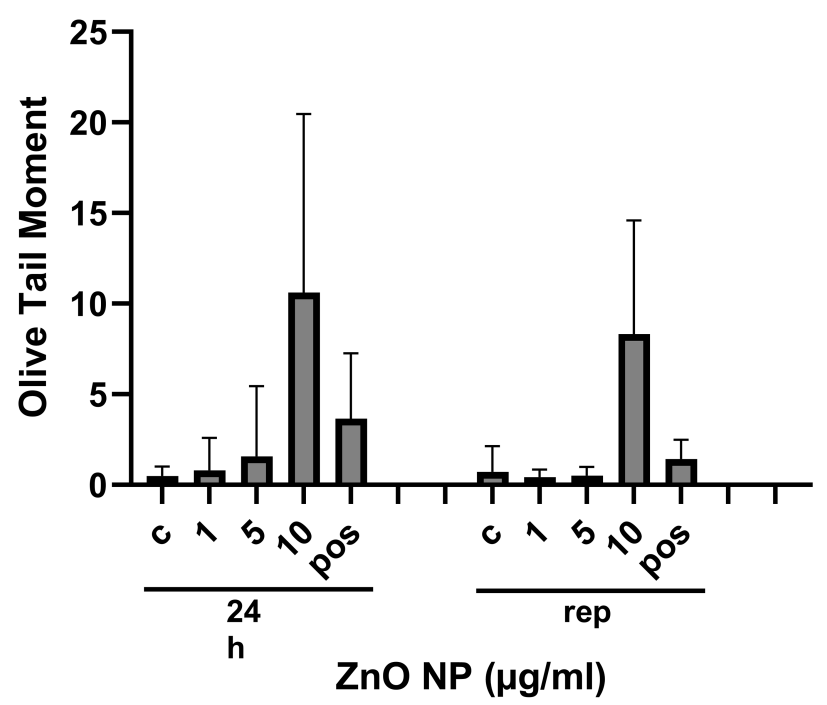

Figure 6 DNA fragmentation expressed by the Olive tail moment (OTM) in HUVEC after exposure to $\mathrm{ZnO} N P s$ ( $\mu \mathrm{g} / \mathrm{mL}$ ). ECGM without $\mathrm{ZnO} N P s$ served as negative control (c) and MMS $200 \mu \mathrm{M}$ as positive control (pos). Graphs show results after $24 \mathrm{hrs}$ long-term ( $24 \mathrm{hrs}$ ) and repetitive (rep) exposure to $\mathrm{ZnO} \mathrm{NP}$ $(\mu \mathrm{g} / \mathrm{mL})$.

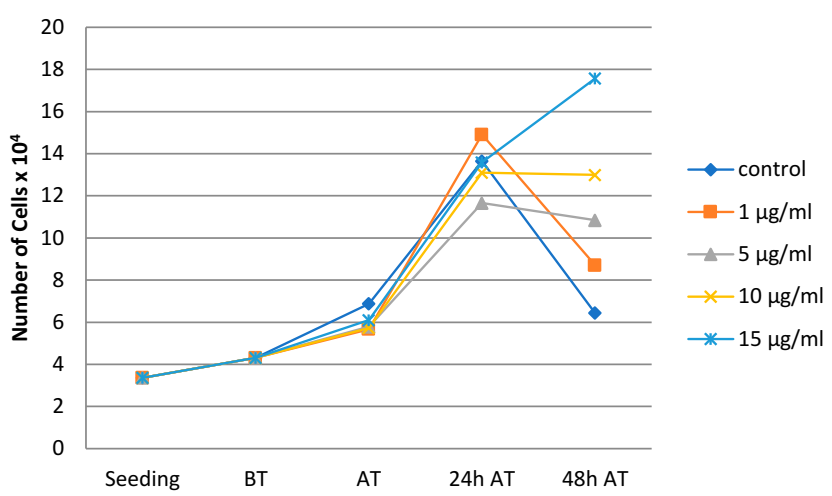

Figure 7 Cell number of HUVEC. Cell number was measured at seeding, before treatment (BT), right after treatment (AT), $24 \mathrm{hrs}$ after treatment (24 hrs AT), and $48 \mathrm{hrs}$ after treatment (48 hrs AT) with I, 5, 10, and I5 $\mathrm{gg} / \mathrm{mL} \mathrm{ZnO}$ NPs. ECGM served as negative control (control). There were no differences until $24 \mathrm{~h}$ AT. Fortyeight hours AT an inverse dose-dependent proliferation rate could be observed. The higher the ZnO NP concentration, the better HUVEC could proliferate. We interpret this as a sign that cells reach the limit of the well earlier when they are exposed to lower concentrations of $\mathrm{ZnO} N P s$.

concentrations and the negative control within $24 \mathrm{hrs}$ after long-term treatment. Forty-eight hrs after treatment cells showed an inverse concentration-related ability to proliferate. While the negative control showed the highest decrease in cell number, ascending $\mathrm{ZnO} \mathrm{NP}$ concentration seemed to lead to an increased ability to further proliferate (Figure 7).

The dot blot assay indicated less VEGF release in HUVEC treated with sub-cytotoxic concentrations of $\mathrm{ZnO}$ NPs compared to the negative control (Figure 8).

The capillary tube formation assay indicated a decrease in the number of meshes and nodes, as well as in the length of tubes. The number of meshes showed a significant dose-dependent decrease $(p=0.033)$, whereas the number of nodes and length of tubes did not $(p=0.053$ for both) (Figures 9 and 10).

\section{Discussion}

$\mathrm{ZnO}$ NPs are essential components of medical solutions, cosmetic products and dietary supplements. ${ }^{49}$ There is no doubt that ZnO NPs come into contact with human cells in a variety of different ways; however, it is not clear exactly how they affect uncompromised cells and tissues. In this regard, a balance between human health risks and economic benefits has to be considered for nanomaterials in general. ${ }^{37}$ Risk stratification becomes more and more indispensable.

The primary aim of this study is to define thresholds for cytotoxicity of ZnO NPs in HUVEC after long-term exposure. In accordance with results from another study, ${ }^{15}$ we found cytotoxic effects and increased apoptosis and necrosis in concentrations above $25 \mu \mathrm{g} / \mathrm{mL}$. Paszek et al demonstrated time- and dose-dependent changes in cell membranes and 
A

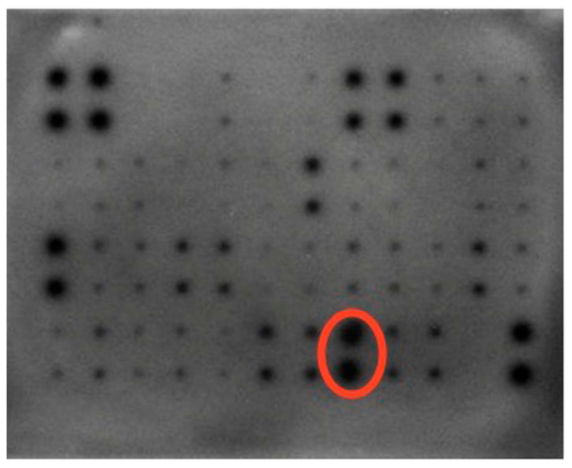

B

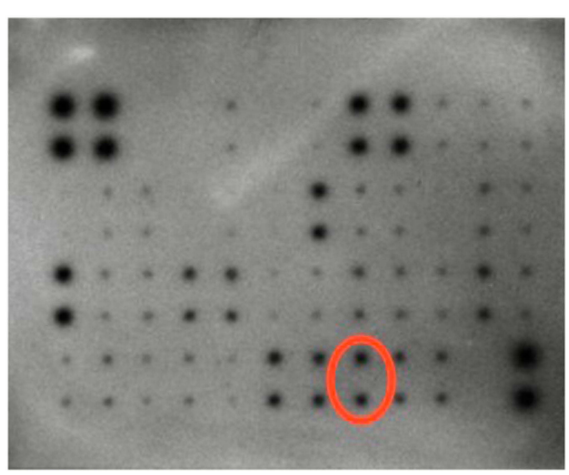

C

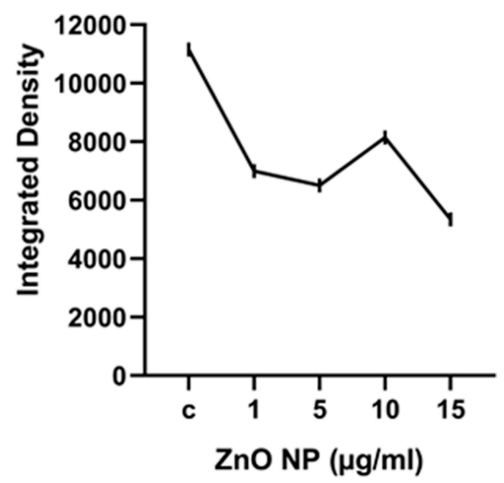

Figure 8 Dot blot. Dot blot indicated less VEGF release in HUVEC treated with ZnO NPs. Pictures of the negative control (A) and $5 \mu$ g/mL (B) show VEGF dots highlighted by red ellipses. Graph (C) shows the integrated density of the VEGF dots released by HUVEC after exposure to ECGM (c; negative control) and ZnO NPs ( $\mu$ g/ $\mathrm{mL}$ ) analyzed with Image].

A

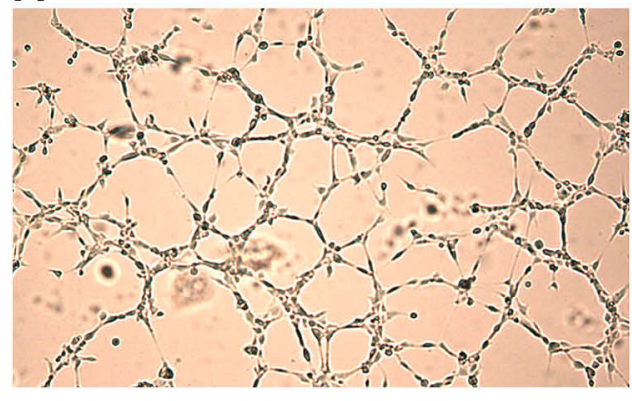

B

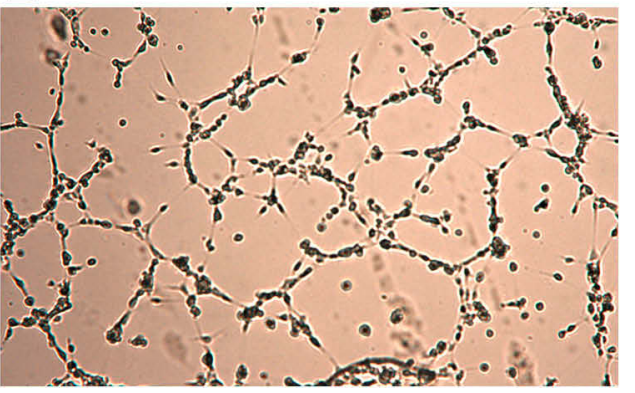

Figure 9 Capillary tube formation assay. This assay indicated functional decrease in HUVEC after exposure to ZnO NPs. The pictures show tube formation after treatment with ECGM ((A); negative control) and $15 \mu \mathrm{g} / \mathrm{mL}$ ZnO NPs (B). Tube formation was analyzed automatically by ImageJ with the Angiogenesis Analyzer plugin.

A

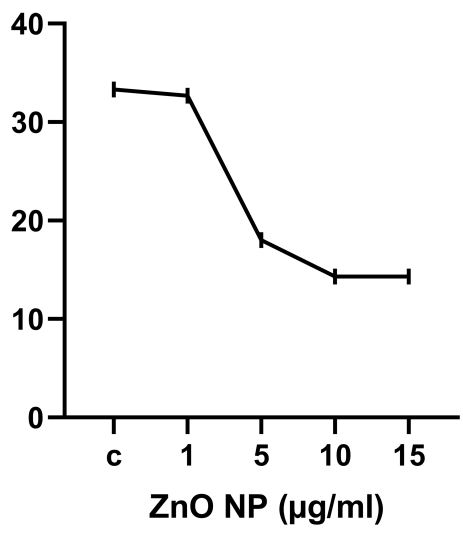

B

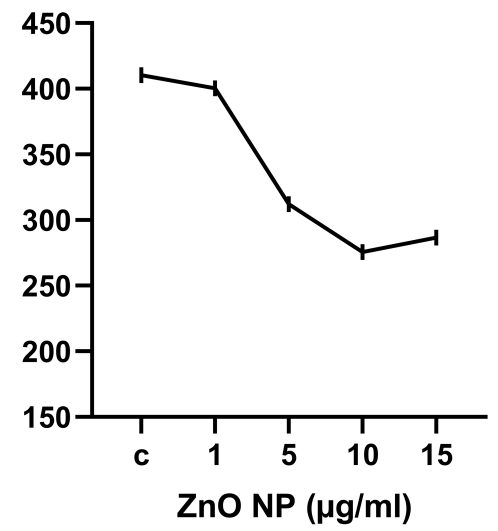

C

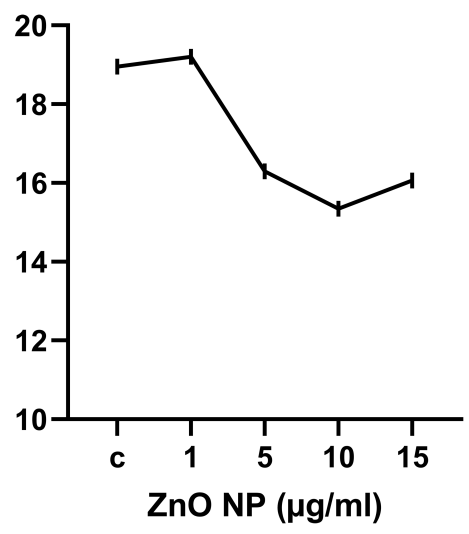

Figure 10 Capillary tube formation assay showed a decrease in the number of meshes $(\mathbf{A})$, number of nodes $(\mathbf{B})$ and length of tubes $((\mathbf{C})$, length of tubes in mm). While the number of meshes decreased significantly $(P=0.033)$, the number of nodes and length of tubes did not decrease significantly $(p=0.053$ for both).

cytoskeleton of HUVEC after a single exposure of 4 and $24 \mathrm{hrs} .{ }^{15}$ In addition to these findings we could reveal comparable cytotoxic effects after repetitive exposure, DNA- damage after long-term and repetitive exposure and show functional impairment in the expression of VEGF and the formation of tubes. 
Numerous studies have proven that $\mathrm{ZnO}$ NPs induce DNA damage in various cell systems, ${ }^{8,29,31,49}$ and determining the underlying mechanisms of these effects has been the objective of many recent investigations. The small size, large surface area and physicochemical characteristics of ZnO NPs, as well as the fact that they can be transferred into intracellular compartments via various mechanisms, are crucial factors in nanocytotoxicology and nanogenotoxicology of $\mathrm{ZnO} .^{49,50}$ Our results show that product information does not necessarily match the characteristics of NPs observed in the laboratory. Therefore, we recommend to analyze and describe NPs detailed in order to provide comparable data. Zeta potential, the electrokinetic potential in colloidal dispersions ${ }^{51}$ and the polydispersity index, measurement of the spread of the relative molecular mass ${ }^{52}$ are widely used to describe NPs in suspension.

Different mechanisms may contribute to the toxic effects of $\mathrm{ZnO}$ NPs. Bai et al revealed mitochondrial dysfunction leading to an increased ROS generation and consecutive DNA damage and cell death. ${ }^{53}$ Another study indicated a stimulation of ROS production via the upregulation of lipoxygenases in neuroblastoma cells. ${ }^{54}$ It has been suggested that the dissolution of $\mathrm{ZnO}$ NPs into $\mathrm{Zn}^{2+}$ ions and consecutive ROS generation after incorporation may be responsible for the genotoxic effects. ${ }^{50,55}$ This seems to be all the more likely since zinc serves as a component of many intracellular enzymes and transcription factors in the human organism. ${ }^{27,32,56}$ Whether ZnO NPs induce cytotoxicity at lower concentrations in cancer cells than in normal cells is discussed controversially. ${ }^{21,57,58}$ This is an important question to answer the more so as they are discussed as promising agents for drug delivery in cancer therapy. ${ }^{59}$

In our study, we observe dose-dependent DNA damage after treatment with $\mathrm{ZnO}$ NPs in sub-cytotoxic concentrations in HUVEC, which may affect the neo-angiogenesis. Considering the application of sunscreens this could be a problem in damaged skin. On the other hand, it could be beneficial in fast-growing tissues like tumors.

Since Vermylen et al state in their review that particulate air pollutants can enter the circulatory system by ingestion and inhalation and cause coronary heart disease, there is increasing scientific interest regarding the underlying mechanisms of how NPs affect the vascular system. ${ }^{60}$ Despite intensive investigation, especially on $\mathrm{ZnO} \mathrm{NPs}$, there is still a considerable lack of data concerning the impact of NP on HUVEC as a primary cell model for the specific microvascular endothelial system. In our present study we demonstrate functional impairment of HUVEC in different observations as a function of various sub-cytotoxic $\mathrm{ZnO} \mathrm{NP}$ concentrations. Monitoring the proliferation rate of the HUVEC cells in the first $24 \mathrm{hrs}$ after exposure, no differences were seen between cells exposed to ZnO NPs and non-treated cells. After another $24 \mathrm{hrs}$, the negative control showed a distinct constriction in its ability to proliferate, whereas NPexposed cells proliferated depending on NP concentration. This may be a consequence of the cells reaching the limit of the wells earlier when they are exposed to lower NP concentrations. VEGF secretion was also measured as a representative protein for the induction of blood vessel formation. The present study shows that the production of VEGF is severely limited in a dose-dependent manner in sub-cytotoxic concentrations in HUVEC. Finally, when analyzing the ability of HUVEC to form typical tubes, nodes and meshes as their primary function, a decreasing ability was demonstrated in correlation with increasing concentrations of ZnO NPs. With regard to HUVEC, these findings suggest a lack of neoangiogenesis under the influence of $\mathrm{ZnO}$ NPs. Again this may have negative effects particularly in pre-damaged tissues and at the same time, it may help to decelerate tumor progression.

In general, $\mathrm{ZnO} \mathrm{NP}$ exposure can be considered repetitive in workers as well as consumers and patients. However, the available literature clearly focuses on single exposure settings. Our study group previously demonstrated that repetitive exposure results in persistent or ongoing DNA damage in various cell lines. ${ }^{30,31}$ In the present study, no difference between long-term or repetitive exposure to sub-cytotoxic concentrations of $\mathrm{ZnO}$ NPs was seen, since both exposure modalities induce cell death and increase DNA fragmentation in a comparable manner.

Still, there is only limited information available about the genotoxic effects and functional impairment caused by $\mathrm{ZnO}$ NPs. Particularly, the underlying molecular mechanisms need further investigation. Dissolved $\mathrm{Zn}^{2+}$ ions and ROS generation seem to be relevant mechanisms in cyto- and genotoxicity caused by $\mathrm{ZnO} \mathrm{NPs},{ }^{61}$ thus we recommend further investigation on the basis of tissue cultures. Analysis of ZnO NPs' behavior in the structure of tissues may contribute to our understanding of how they affect human cells. Especially the degree of dissolution to ionized $\mathrm{Zn}^{2+}$ should be elucidated.

\section{Conclusion}

In the present study thresholds for cytotoxicity of $\mathrm{ZnO}$ NPs in HUVEC could be defined. Furthermore, genotoxic effects were demonstrated after long-term and repetitive 
exposure. In several modalities, functional impairment in the microvascular endothelial model caused by ZnO NPs was proven. This investigation indicates the anti-angiogenic effects of $\mathrm{ZnO}$ NPs.

\section{Acknowledgment}

Supported by Johannes Kepler Open Access Publishing Fund.

\section{Disclosure}

The authors report no conflicts of interest in this work.

\section{References}

1. Scherzad A, Meyer T, Kleinsasser N, Hackenberg S. Molecular mechanisms of zinc oxide nanoparticle-induced genotoxicity short running title: genotoxicity of $\mathrm{ZnO}$ NPs. Materials. 2017;10 (12):1427. doi:10.3390/ma10121427

2. Osmond MJ, McCall MJ. Zinc oxide nanoparticles in modern sunscreens: an analysis of potential exposure and hazard. Nanotoxicology. 2010;4(1):15-41. doi:10.3109/17435390903502028

3. EUROPEAN COMMISSION. Commission Recommendation of 18 October 2011 on the definition of nanomaterial. Off $J$ Eur Union. 2011;275:38

4. Sahu D, Kannan GM, Vijayaraghavan R, Anand T, Khanum F. Nanosized zinc oxide induces toxicity in human lung cells. ISRN Toxicol. 2013;2013:1-8. doi:10.1155/2013/316075

5. Cross SE, Innes B, Roberts MS, Tsuzuki T, Robertson TA, McCormick P. Human skin penetration of sunscreen nanoparticles: in-vitro assessment of a novel micronized zinc oxide formulation. Skin Pharmacol Physiol. 2007;20(3):148-154. doi:10.1159/000098701

6. Hayden CGJ, Cross SE, Anderson C, Saunders NA, Roberts MS. Sunscreen penetration of human skin and related keratinocyte toxicity after topical application. Skin Pharmacol Physiol. 2005;18(4):170 174. doi: $10.1159 / 000085861$

7. Demir E, Akça H, Kaya B, et al. Zinc oxide nanoparticles: genotoxicity, interactions with UV-light and cell-transforming potential. $J$ Hazard Mater. 2014;264:420-429. doi:10.1016/j.jhazmat.2013.11.043

8. Sharma V, Singh SK, Anderson D, Tobin DJ, Dhawan A. Zinc oxide nanoparticle induced genotoxicity in primary human epidermal keratinocytes. J Nanosci Nanotechnol. 2011;11(5):3782-3788. doi:10.1166/ jnn.2011.4250

9. Gulson B, McCall M, Korsch M, et al. Small amounts of zinc from zinc oxide particles in sunscreens applied outdoors are absorbed through human skin. Toxicol Sci. 2010;118(1):140-149. doi:10.1093/toxsci/kfq243

10. Gehrke T, Scherzad A, Ickrath P, et al. Zinc oxide nanoparticles antagonize the effect of Cetuximab on head and neck squamous cell carcinoma in vitro. Cancer Biol Ther. 2017;18(7):513-518. doi:10.1080/15384047.2017.1323598

11. Nemmar A, Nemery B, Hoylaerts MF, Vermylen J. Air pollution and thrombosis: an experimental approach. Pathophysiol Haemost Thromb. 2002;32(5-6):349-350. doi:10.1159/000073597

12. Bengalli R, Gualtieri M, Capasso L, Urani C, Camatini M. Impact of zinc oxide nanoparticles on an in vitro model of the human air-blood barrier. Toxicol Lett. 2017;279:22-32. doi:10.1016/j.toxlet.2017.07.877

13. Nemmar A, Vanbilloen H, Hoylaerts MF, Hoet PH, Verbruggen A, Nemery B. Passage of intratracheally instilled ultrafine particles from the lung into the systemic circulation in hamster. Am J Respir Crit Care Med. 2001;164(9):1665-1668. doi:10.1164/ajrccm.164.9. 2101036
14. Sun J, Wang S, Zhao D, Hun FH, Weng L, Liu H. Cytotoxicity, permeability, and inflammation of metal oxide nanoparticles in human cardiac microvascular endothelial cells. Cell Biol Toxicol. 2011;27(5):333-342. doi:10.1007/s10565-011-9191-9

15. Paszek E, Czyz J, Woźnicka O, et al. Zinc oxide nanoparticles impair the integrity of human umbilical vein endothelial cell monolayer in vitro. J Biomed Nanotechnol. 2012;8(6):957-967. doi:10.1166/ jbn.2012.1463

16. Suzuki Y, Tada-Oikawa S, Ichihara G, et al. Zinc oxide nanoparticles induce migration and adhesion of monocytes to endothelial cells and accelerate foam cell formation. Toxicol Appl Pharmacol. 2014;278 (1):16-25. doi:10.1016/j.taap.2014.04.010

17. Yan Z, Wang W, Wu Y, et al. Zinc oxide nanoparticle-induced atherosclerotic alterations in vitro and in vivo. Int $J$ Nanomedicine. 2017;12:4433-4442. doi:10.2147/IJN.S134897

18. Gojova A, Guo B, Kota RS, Rutledge JC, Kennedy IM, Barakat AI. Induction of inflammation in vascular endothelial cells by metal oxide nanoparticles: effect of particle composition. Environ Health Perspect. 2007;115(3):403-409. doi:10.1289/ehp.8497

19. Chuang K-J, Lee K-Y, Pan C-H, et al. Effects of zinc oxide nanoparticles on human coronary artery endothelial cells. Food Chem Toxicol. 2016;93:138-144. doi:10.1016/j.fct.2016.05.008

20. Tsou T-C, Yeh S-C, Tsai F-Y, et al. Zinc oxide particles induce inflammatory responses in vascular endothelial cells via NF- $\kappa \mathrm{B}$ signaling. J Hazard Mater. 2010;183(1-3):182-188. doi:10.1016/j. jhazmat.2010.07.010

21. Mortezaee K, Najafi M, Samadian H, Barabadi H, Azarnezhad A, Ahmadi A. Redox interactions and genotoxicity of metal-based nanoparticles: a comprehensive review. Chem Biol Interact. 2019;312:108814. doi:10.1016/j.cbi.2019.108814

22. Ancona A, Dumontel B, Garino N, et al. Lipid-coated zinc oxide nanoparticles as innovative ROS-generators for photodynamic therapy in cancer cells. Nanomaterials. 2018;8(3):143. doi:10.3390/ nano8030143

23. Ng CT, Yong LQ, Hande MP, et al. Zinc oxide nanoparticles exhibit cytotoxicity and genotoxicity through oxidative stress responses in human lung fibroblasts and Drosophila melanogaster. Int $J$ Nanomedicine. 2017;12:1621-1637. doi:10.2147/IJN.S124403

24. Chevallet M, Gallet B, Fuchs A, et al. Metal homeostasis disruption and mitochondrial dysfunction in hepatocytes exposed to sub-toxic doses of zinc oxide nanoparticles. Nanoscale. 2016;8(43):1849518506. doi:10.1039/c6nr05306h

25. Mihai C, Chrisler WB, Xie Y, et al. Intracellular accumulation dynamics and fate of zinc ions in alveolar epithelial cells exposed to airborne $\mathrm{ZnO}$ nanoparticles at the air-liquid interface. Nanotoxicology. 2015;9(1):922. doi:10.3109/17435390.2013.859319

26. Huang -C-C, Aronstam RS, Chen D-R, Huang Y-W. Oxidative stress, calcium homeostasis, and altered gene expression in human lung epithelial cells exposed to $\mathrm{ZnO}$ nanoparticles. Toxicol in Vitro. 2010;24(1):45-55. doi:10.1016/j.tiv.2009.09.007

27. Saptarshi SR, Duschl A, Lopata AL. Biological reactivity of zinc oxide nanoparticles with mammalian test systems: an overview. Nanomedicine. 2015;10(13):2075-2092. doi:10.2217/nnm.15.44

28. Kwon JY, Lee SY, Koedrith P, et al. Lack of genotoxic potential of $\mathrm{ZnO}$ nanoparticles in in vitro and in vivo tests. Mutat Res Genet Toxicol Environ Mutagen. 2014;761:1-9. doi:10.1016/j.mrgentox.. 2014.01.005

29. Ghosh M, Sinha S, Jothiramajayam M, Jana A, Nag A, Mukherjee A. Cyto-genotoxicity and oxidative stress induced by zinc oxide nanoparticle in human lymphocyte cells in vitro and Swiss albino male mice in vivo. Food Chem Toxicol. 2016;97:286-296. doi:10.1016/j. fct.2016.09.025

30. Hackenberg S, Zimmermann F-Z, Scherzed A, et al. Repetitive exposure to zinc oxide nanoparticles induces DNA damage in human nasal mucosa mini organ cultures. Environ Mol Mutagen. 2011;52(7):582-589. doi:10.1002/em.20661 
31. Ickrath P, Wagner M, Scherzad A, et al. Time-dependent toxic and genotoxic effects of zinc oxide nanoparticles after long-term and repetitive exposure to human mesenchymal stem cells. Int J Environ Res Public Health. 2017;14(12):1590. doi:10.3390/ijerph14121590

32. Li L-Z, Zhou D-M, J G W, et al. Toxicity of zinc oxide nanoparticles in the earthworm, Eisenia fetida and subcellular fractionation of $\mathrm{Zn}$. Environ Int. 2011;37(6):1098-1104. doi:10.1016/j.envint.2011.01.008

33. Enrique M-A, Mariana O-R, Mirshojaei SF, Ahmadi A. Multifunctional radiolabeled nanoparticles: strategies and novel classification of radiopharmaceuticals for cancer treatment. J Drug Target. 2015;23(3):191-201. doi:10.3109/1061186X.2014.988216

34. Mirshojaei SF, Ahmadi A, Morales-Avila E, Ortiz-Reynoso M, Reyes-Perez H. Radiolabelled nanoparticles: novel classification of radiopharmaceuticals for molecular imaging of cancer. J Drug Target. 2016;24(2):91-101. doi:10.3109/1061186X.2015.1048516

35. Pokrowiecki R, Wojnarowicz J, Zareba T, et al. Nanoparticles and human saliva: a step towards drug delivery systems for dental and craniofacial biomaterials. Int J Nanomedicine. 2019;14:9235-9257. doi:10.2147/IJN.S221608

36. Wang J, Gao S, Wang S, Xu Z, Wei L. Zinc oxide nanoparticles induce toxicity in CAL 27 oral cancer cell lines by activating PINK1/ Parkin-mediated mitophagy. Int J Nanomedicine. 2018;13:34413450. doi:10.2147/IJN.S165699

37. Samadian H, Salami MS, Jaymand M, et al. Genotoxicity assessment of carbon-based nanomaterials; Have their unique physicochemical properties made them double-edged swords? Mutat Res Rev Mutat Res. 2020;783:108296. doi:10.1016/j.mrrev.2020.108296

38. Hinderlich S, Neuenschwander M, Wratil PR, et al. Small molecules targeting human $\mathrm{N}$-acetylmannosamine kinase. ChemBioChem. 2017;18(13):1279-1285. doi:10.1002/cbic.201700066

39. Bihari P, Vippola M, Schultes S, et al. Optimized dispersion of nanoparticles for biological in vitro and in vivo studies. Part Fibre Toxicol. 2008;5(1):14. doi:10.1186/1743-8977-5-14

40. Scherzed A, Hackenberg S, Froelich K, et al. The differentiation of hMSCs counteracts their migration capability and pro-angiogenic effects in vitro. Oncol Rep. 2016;35(1):219-226. doi:10.3892/ or.2015.4383

41. Mosmann T. Rapid colorimetric assay for cellular growth and survival: application to proliferation and cytotoxicity assays. J Immunol Methods. 1983;65(1-2):55-63. doi:10.1016/0022-1759(83)90303-4

42. Tice RR, Agurell E, Anderson D, et al. Single cell gel/comet assay: guidelines for in vitro and in vivo genetic toxicology testing. Environ Mol Mutagen. 2000;35:206-221. doi:10.1002/(SICI)1098-2280 (2000)35:3<206::AID-EM8>3.0.CO;2-J

43. Scherzad A, Hackenberg S, Schramm C, et al. Geno- and cytotoxicity of salinomycin in human nasal mucosa and peripheral blood lymphocytes. Toxicol in Vitro. 2015;29(4):813-818. doi:10.1016/j. tiv.2015.01.018

44. Ginzkey C, Stueber T, Friehs G, et al. Analysis of nicotine-induced DNA damage in cells of the human respiratory tract. Toxicol Lett. 2012;208(1):23-29. doi:10.1016/j.toxlet.2011.09.029

45. Olive PL, Durand RE, Le Riche J, Olivotto IA, Jackson SM. Gel electrophoresis of individual cells to quantify hypoxic fraction in human breast cancers. Cancer Res. 1993;53:733-736.
46. DeCicco-Skinner KL, Henry GH, Cataisson C, et al. Endothelial cell tube formation assay for the in vitro study of angiogenesis. J Vis Exp. 2014;91):e51312. doi:10.3791/51312

47. Carpentier G. ImageJ contribution: angiogenesis analyzer. ImageJ News. 2012

48. Zimmerman DW, Zumbo BD. Relative power of the Wilcoxon test, the Friedman test, and repeated-measures ANOVA on ranks. J Exp Educ. 1993;62(1):75-86. doi:10.1080/00220973.1993.9943832

49. Hackenberg S, Scherzed A, Zapp A, et al. Genotoxic effects of zinc oxide nanoparticles in nasal mucosa cells are antagonized by titanium dioxide nanoparticles. Mutat Res Genet Toxicol Environ Mutagen. 2017;816-817:32-37. doi:10.1016/j.mrgentox.2017.02.005

50. De Berardis B, Civitelli G, Condello M, et al. Exposure to $\mathrm{ZnO}$ nanoparticles induces oxidative stress and cytotoxicity in human colon carcinoma cells. Toxicol Appl Pharmacol. 2010;246(3):116127. doi:10.1016/j.taap.2010.04.012

51. Nič M, Jirát J, Košata B, Jenkins A, McNaught A, editors. electrokinetic potential, $\zeta$. IUPAC compendium of chemical terminology. 2.1 .0 ed. Research Triangle Park, NC: IUPAC. 2009. doi:10.1351/ goldbook.E01968

52. Stepto RFT. Dispersity in polymer science (IUPAC Recommendations 2009). J Macromol Sci Part a Pure Appl Chem. 2009;81(2):351-353. doi:10.1351/PAC-REC-08-05-02

53. Bai D-P, Zhang X-F, Zhang G-L, Huang Y-F, Gurunathan S. Zinc oxide nanoparticles induce apoptosis and autophagy in human ovarian cancer cells. Int $J$ Nanomedicine. 2017;12:6521-6535. doi:10.2147/IJN.S140071

54. Kim J-H, Jeong MS, Kim D-Y, Her S, Wie M-B. Zinc oxide nanoparticles induce lipoxygenase-mediated apoptosis and necrosis in human neuroblastoma SH-SY5Y cells. Neurochem Int. 2015;90:204-214. doi:10.1016/j.neuint.2015.09.002

55. Fukui H, Horie M, Endoh S, et al. Association of zinc ion release and oxidative stress induced by intratracheal instillation of $\mathrm{ZnO}$ nanoparticles to rat lung. Chem Biol Interact. 2012;198(1-3):29-37. doi:10.1016/j.cbi.2012.04.007

56. Song W, Zhang J, Guo J, et al. Role of the dissolved zinc ion and reactive oxygen species in cytotoxicity of $\mathrm{ZnO}$ nanoparticles. Toxicol Lett. 2010;199(3):389-397. doi:10.1016/j.toxlet.2010.10.003

57. Nair S, Sasidharan A, Divya Rani VV, et al. Role of size scale of ZnO nanoparticles and microparticles on toxicity toward bacteria and osteoblast cancer cells. J Mater Sci Mater Med. 2009;20(Suppl 1): S235-41. doi:10.1007/s10856-008-3548-5

58. Sharma V, Shukla RK, Saxena N, Parmar D, Das M, Dhawan A. DNA damaging potential of zinc oxide nanoparticles in human epidermal cells. Toxicol Lett. 2009;185(3):211-218. doi:10.1016/j.toxlet.2009.01.008

59. Deng Y, Zhang H. The synergistic effect and mechanism of doxorubicin- $\mathrm{ZnO}$ nanocomplexes as a multimodal agent integrating diverse anticancer therapeutics. Int J Nanomedicine. 2013;8:1835-1841. doi: $10.2147 /$ IJN.S43657

60. Vermylen J, Nemmar A, Nemery B, Hoylaerts MF. Ambient air pollution and acute myocardial infarction. J Thromb Haemost. 2005;3(9):1955-1961. doi:10.1111/j.1538-7836.2005.01471.x

61. Vandebriel R, De Jong W. A review of mammalian toxicity of $\mathrm{ZnO}$ nanoparticles. Nanotechnol Sci Appl. 2012;61. doi:10.2147/nsa. s23932

International Journal of Nanomedicine

\section{Publish your work in this journal}

The International Journal of Nanomedicine is an international, peerreviewed journal focusing on the application of nanotechnology in diagnostics, therapeutics, and drug delivery systems throughout the biomedical field. This journal is indexed on PubMed Central, MedLine, CAS, SciSearch ${ }^{\circledR}$, Current Contents ${ }^{\mathbb{B}} /$ Clinical Medicine,

Journal Citation Reports/Science Edition, EMBase, Scopus and the Elsevier Bibliographic databases. The manuscript management system is completely online and includes a very quick and fair peer-review system, which is all easy to use. Visit http://www.dovepress.com/ testimonials.php to read real quotes from published authors. 